\title{
Diathesis on Twitter Tweets of Teenagers
}

\author{
Diatesis dalam Kicauan Twitter Anak Usia Remaja
}

Vol. 1, No. 1 ,

October 2019

pp. 14-18

Nicky Rosadi

Universitas Indraprasta PGRI

Jalan Raya Tengah No.80, RT.6/RW.1, Gedong, Kec. Ps. Rebo, Kota Jakarta Timur, Daerah Khusus Ibukota Jakarta 13760

\begin{abstract}
The purpose of this research was to know diathesis contained in Twitter tweets of teenagers. Research conducted in Jakarta, during the even semester of the 2014/2015 academic year used a qualitative descriptive analysis method with content analysis. The object of this research is Twitter text written by teenagers. The instrument used in this study was the researcher himself who was assisted by the data analysis table. Based on the results of the analysis, it can be seen that the most common diathesis is active diathesis with the appearance of $40 \%$ of the total data available. Second is a causative diathesis with the occurrence of $21.54 \%$ of the total data. From the two biggest occurrences, it is seen that diathesis that refers to active actions/actions is the most widely used. So, it can be concluded that Twitter tweets of teenagers are more dominant using active diathesis
\end{abstract}

Keywords: diathesis, Twitter tweets, teenagers.

\section{PENDAHULUAN}

Twitter menjadi populer di kalangan remaja karena kepraktisannya dalam hal penggunaan. Dengan Twitter, para remaja saling menjalin hubungan dengan temantemannya, baik teman dekat maupun teman lama yang sudah jauh berpisah. Twitter seakan mendekatkan mereka. Kemudahan inilah yang akhirnya dimanfaatkan mereka untuk saling memberi informasi dalam bentuk kicauan. Tak jarang, mereka juga sering meluapkan perasaannya pada media sosial yang satu ini.

Kajian tentang diatesis dalam tata bahasa menjadi pokok bahasan penting dan menantang untuk ditelaah. Secara teoritis, persoalan diatesis merupakan interaksi antara tataran morfosintaksis dengan semantis. Sehubungan dengan itu, fenomena diatesis bukan hanya berkaitan dengan bentuk bahasa (language form), tetapi juga berkenaan dengan makna bahasa (language meaning), yang pada beberapa bagiannya berhubungan dengan logika, penalaran, dan muatan abstrak bahasa. Pertautan antara bentuk dengan makna bahasa memungkinkan bahasa berfungsi sebagai alat komunikasi penting dalam kehidupan manusia. Bahasa merupakan fenomena perorangan dan sekaligus merupakan fenomena sosial.

Berdasarkan kerangka teoritis, tipologi linguistik, bahasa-bahasa dapat dikelompokkan menjadi bahasa akusatif, bahasa ergatif, bahasa aktif, dan sebagainya. Dalam kaitannya dengan diatesis, bahasa akusatif mempunyai diatesis aktif (diatesis konstruksi dasar) dan pasif (diatesis konstruksi turunan). Sedangkan bahasa ergatif mengenal adanya diatesis ergatif (diatesis konstruksi dasar) dan diatesis antipasif (diatesis konstruksi turunan). Dengan kata lain, konstruksi klausa berdiatesis aktif (pada bahasa akusatif) dan yang berdiatesis ergatif (pada bahasa ergatif) merupakan diatesis dasar, sedangkan diatesis pasif (pada bahasa akusatif) dan diatesis antipasif (pada bahasa ergatif) adalah diatesis turunan (Artawa, 2002).

Pada umumnya, bahasa-bahasa di dunia ini mempunyai strategi diatesis dasar; diatesis aktif-pasif. Pertentangan aktif-pasif merujuk ke pertentangan semantis. Pada diatesis, 
subjek bertindak atas yang lain atau mempengaruhi yang lain, sementara dalam diatesis pasif, subjek dipengaruhi atau tempat jatuhnya perbuatan. Diatesis adalah kategori gramatikal yang menunjukkan hubungan antara partisipan/subjek dengan perbuatan yang dinyatakan oleh verba dalam klausa. Di Indonesia, istilah diatesis lebih dikenal dengan istilah voice.(Kridalaksana, 2011)

Atas dasar itulah, akan diteliti proposisi dan diatesis dalam kicauan Twitter anak usia remaja. Penelitian tentang proposisi dan diatesis bukan berarti tidak dapat dilakukan pada teks lain, namun penulis memilih kicauan Twitter anak usia remaja karena penulis menganggap teks ini lebih menarik untuk diteliti.

\section{Diatesis}

Istilah diatesis dalam gramatika Inggris lazim disebut voice, yakni salah satu subkategori makna (meaning categories) yang mengindikasikan relasi antara partisipan dengan aksi. "Voice indicates the relationship of participants to the action". Meskipun terdapat dalam hubungan sintaktis, indikasi voice itu tampak pula pada sistem afiks verbal atau kelas kata lainnya. Apa yang disebut voice itu mencakup (a) aktif, bila subjek sebagai pelaku aksi; (b) pasif, bila subjek menjadi tujuan aksi; (c) reflektif, bila subjek beraksi pada dirinya; (d) resiprokal, apabila subjek jamak beraksi secara berbalasan; (e) kausatif, bila aktor terkena keadaan atau kejadian; (f) benefaktif, bila aktor beraksi untuk orang lain (Elson \& Velma, 1982: 24)

Berkaitan dengan makna inheren verba, Quirk \& Randolp, (1987:74) memilah verba atas (1) verba dinamis dan (2) verba statif, yang masing-masing memiliki subkategori tersendiri. Situasi dinamis dan statif, menurut Givon(1984: 55), berkaitan dengan skala stabilitas waktu (time-stability scale), ada yang tinggi (most time-stable), ada yang mudah berubah (rapid change), ada yang tengah-tengah (interma- diate states). Verba yang mudah berubah dan bergerak mengacu pada verba dinamis, sedangkan yang relatif tetap sebagai sebuah keadaan mengacu pada verba statif

Jadi, dapat disimpulkan bahwa diatesis adalah salah satu subkategori makna (meaning categories) yang mengindikasikan relasi antara partisipan dengan aksi. Diatesis mencakup (a) aktif, bila subjek sebagai pelaku aksi; (b) pasif, bila subjek menjadi tujuan aksi; (c) refleksif, bila subjek beraksi pada dirinya; (d) resiprokal, apabila subjek jamak beraksi secara berbalasan; (e) kausatif, bila aktor terkena keadaan atau kejadian; (f) benefaktif, bila aktor beraksi untuk orang lain.

\section{Twitter}

Twitter adalah layanan jejaring sosial dan microblogging gratis yang memungkinkan pengguna mengirim dan menerima pesan sepanjang 140 karakter, tanpa foto dan video. Twitter dapat diakses dengan internet berkecepatan lambat karena pesan yang ada dalam Twitter memang hanya teks, yang berkapasitas sangat kecil. Seorang penulis pesan (tweet/kicauan) di Twitter disebut author. Pesan-pesan itu dapat dibaca orang lain, yang disebut follower (pengikut).

\section{METODE}

Metode dalam penelitian ini yaitu metode deskriptif kualitatif dengan teknik analisis isi. Objek penelitian ini adalah teks yang terdapat di dalam kicauan Twitter anak usia remaja yang diambil dari situs www.twitter.com. Instrumen dalam penelitian ini adalah peneliti sendiri dibantu dengan tabel analisis yang memuat proposisi dan diatesis dalam kicauan Twitter anak usia remaja. Teknik analisis data yang digunakan adalah reduksi data, penyajian data, penarikan kesimpulan dilakukan selama proses penelitian berlangsung. 


\section{HASIL DAN PEMBAHASAN}

Hasil

Diatesis atau voice itu berkenaan dengan peran aktor dan sasaran, baik sebagai peran "terlengket" maupun peran "teraktualisasi". Apa yang disebut diatesis itu mencakup (a) aktif, bila subjek sebagai pelaku aksi; (b) pasif, bila subjek menjadi tujuan aksi; (c) reflektif, bila subjek beraksi pada dirinya; (d) resiprokal, apabila subjek jamak beraksi secara berbalasan; (e) kausatif, bila aktor terkena keadaan atau kejadian; $(f)$ benefaktif, bila aktor beraksi untuk orang lain.

Contoh:

a. Diatesis aktif

Contoh diatesis aktif terdapat pada klausa (1), yaitu:

Mimpi dia mulu

\section{Kesimpulan}

Dalam hal ini, diatesis yang terbentuk adalah diatesis aktif.

b. Diatesis pasif

\section{Kesimpulan}

Contoh diatesis pasif terdapat pada klausa (6), yaitu: Yaadeh terima apa aja

Dalam hal ini, diatesis yang terbentuk adalah diatesis pasif.

c. Diatesis reflektif

\section{Kesimpulan}

Contoh diatesis reflektif terdapat pada klausa (23), yaitu: Jadi bingung

Dalam hal ini, diatesis yang terbentuk adalah diatesis reflektif.

d. Diatesis resiprokal

Contoh diatesis resiprokal tidak terdapat pada data klausa kicauan Twitter anak usia remaja.

e. Diatesis kausatif

\section{Kesimpulan}

Contoh diatesis kausatif terdapat pada klausa (4), yaitu: yang selalu ngasih semangat

Dalam hal ini, diatesis yang terbentuk adalah diatesis kausatif.

f. Diatesis benefaktif

Contoh diatesis benefaktif terdapat pada klausa (18), yaitu: Kepengen bisa marah

\section{Kesimpulan}

Dalam hal ini, diatesis yang terbentuk adalah diatesis benefaktif.

Hasil analisis diatesis terangkum dalam tabel berikut: 
research and development thinking paradigm

Tabel 1.

Rekapitulasi Hasil Analisis Diatesis dalam Kicauan Twitter Anak Usia Remaja

Literatus is a journal published by PT Traindo Bangun Negeri, issued two times in one year. Literatus is a scientific publication media in the form of conceptual paper and field research related to general thinking paradigm. It is hoped that Literatus can become a media for academics and researchers to publish their scientific work and become a reference source for the development of science and knowledge.

Our focus:

Social and Culture

Our Scope:

Humanities,

Education,

Management,

History,

Economics,

Linguistics,

Literature,

Religion,

Politics,

Sociology,

Anthropology,

and others.

\begin{tabular}{cccccccc}
\hline Diatesis & Aktif & Pasif & Reflektif & Resiprokal & Kausatif & Benefaktif & $\begin{array}{c}\text { Total } \\
\text { Diatesis }\end{array}$ \\
\hline $\begin{array}{c}\text { Jumlah } \\
\text { Data }\end{array}$ & 26 & 6 & 12 & 0 & 14 & 7 & 65 \\
\hline
\end{tabular}

Sumber: diolah

Berdasarkan tabel data di atas maka dapat disimpulkan bahwa dari enam puluh lima data yang terdapat dalam kicauan Twitter anak usia remaja, terdapat 26 diatesis aktif, enam diatesis pasif, 12 diatesis refleksif, 14 diatesis kausatif, tujuh diatesis benefaktif, dan tidak ada diatesis resiprokal yang ditemukan pada data.

Diatesis atau voice itu berkenaan dengan peran aktor dan sasaran, baik sebagai peran "terlengket" maupun peran "teraktualisasi". Apa yang disebut diatesis itu mencakup (a) aktif, bila subjek sebagai pelaku aksi; (b) pasif, bila subjek menjadi tujuan aksi; (c) reflektif, bila subjek beraksi pada dirinya; $(d)$ resiprokal, apabila subjek jamak beraksi secara berbalasan; $(e)$ kausatif, bila aktor terkena keadaan atau kejadian; $(f)$ benefaktif, bila aktor beraksi untuk orang lain.

Berdasarkan data yang telah dianalisis, dari enam puluh lima diatesis yang terdapat dalam kicauan Twitter anak usia remaja, terdapat dua puluh enam sebagai diatesis aktif, enam sebagai diatesis pasif, dua belas sebagai diatesis reflektif, empat belas sebagai diatesis kausatif, tujuh sebagai diatesis benefaktif, dan tidak ditemukan bentuk diatesis respirokal pada data yang ada.

Berdasarkan data di atas, dapat diketahui bahwa diatesis yang paling banyak muncul adalah diatesis aktif dengan kemunculan $40 \%$ dari jumlah keseluruhan data yang ada. Kedua adalah diatesis kausatif dengan kemunculan 21,54\% dari jumlah data. Dari kedua kemunculan terbesar tersebut, terlihat bahwa diatesis yang mengacu pada perbuatan/tindakan aktiflah yang paling banyak digunakan. Sehingga, dapat disimpulkan bahwa kicauan Twitter anak usia remaja lebih dominan menggunakan diatesis-diatesis yang aktif.

\section{Pembahasan}

Untuk melihat diatesis sebuah klausa, cukup dengan melihat peran aktor dan sasarannya, baik sebagai peran "terlengket" maupun peran "teraktualisasi". Apa yang disebut diatesis itu mencakup (a) aktif, bila subjek sebagai pelaku aksi; (b) pasif, bila subjek menjadi tujuan aksi; (c) reflektif, bila subjek beraksi pada dirinya; $(d)$ resiprokal, apabila subjek jamak beraksi secara berbalasan; (e) kausatif, bila aktor terkena keadaan atau kejadian; $(f)$ benefaktif, bila aktor beraksi untuk orang lain.

Diatesis yang paling banyak muncul dalam kicauan Twitter anak usia remaja adalah diatesis aktif dengan kemunculan $40 \%$ dari jumlah keseluruhan data yang ada. Diatesis tersebut merupakan diatesis yang mengacu pada perbuatan/tindakan aktif, dalam hal ini ditinjau dari makna predikatornya terhadap peran argumen. Sebagian besar predikator bermakna perbuatan adalah diatesis aktif, beberapa lainnya dibentuk oleh predikator bermakna keadaan. Dari temuan ini, diketahui bahwa diatesis aktiflah yang paling banyak digunakan dalam kicauan Twitter anak usia remaja. Hal ini mengungkapkan bahwa kicauan Twitter anak usia remaja lebih dominan menggambarkan pada tindakan-tindakan aktif terkait dirinya atau pokok pembicaraan lainnya.

Pendapat ini sejalan dengan penelitian terhadap diatesis oleh Jufrizal (2004) dalam bentuk makalah yang membahas tentang diatesis dalam bahasa Minangkabau. Kemudian penelitian tersebut diperkuat kembali oleh Jufrizal, Rusdi, \& Refnita(2008) bahwa secara pragmatis, klausa aktif adalah konstruksi gramatikal yang mementingkan pelaku (agen) dan si penutur menghendaki pelaku menjadi topik pembicaraan. Akan tetapi, karena struktur gramatikal klausa tersebut tidak bersifat tertanda, melainkan tak tertanda saja, maka walaupun 
agen adalah juga topik namun secara keseluruhan tidak terjadi penyebaran dan kemasan informasi yang bersifat istimewa. Semua butir-butir informasi pada klausa seperti itu tidak mempunyai peran psikologis dan pragmatis yang mendapat perlakuan khusus.

\section{PENUTUP}

Berdasarkan enam puluh lima diatesis yang terdapat dalam kicauan Twitter anak usia remaja, terdapat dua puluh enam sebagai diatesis aktif, enam sebagai diatesis pasif, dua belas sebagai diatesis reflektif, empat belas sebagai diatesis kausatif, tujuh sebagai diatesis benefaktif, dan tidak ditemukan bentuk diatesis respirokal pada data yang ada.

Berdasarkan data di atas, dapat diketahui bahwa diatesis yang paling banyak muncul adalah diatesis aktif dengan kemunculan $40 \%$ dari jumlah keseluruhan data yang ada. Kedua adalah diatesis kausatif dengan kemunculan $21,54 \%$ dari jumlah data. Dari kedua kemunculan terbesar tersebut, terlihat bahwa diatesis yang mengacu pada perbuatan/tindakan aktiflah yang paling banyak digunakan. Sehingga, dapat disimpulkan bahwa kicauan Twitter anak usia remaja lebih dominan menggunakan diatesis-diatesis yang aktif.

\section{DAFTAR PUSTAKA}

Artawa. (2002). Ergativy and Gramatikal Relation. Linguistika Volume 9 No.16 , 15-26.

Elson, B., \& Velma, P. (1982). Beginning to Morphology and Syntax. . Dallas: The SIL.

Givon, T. (1984). Syntax: A Functional Typological Introduction. Philadelphia: John Benjamins Publishing Company.

Jufrizal, Rusdi, \& Refnita, L. (2009). Struktur Informasi pada Klausa Bahasa Minangkabau. Lingua Didaktika, 2(4), 58-69. Diambil dari http://ejournal.unp.ac.id/index.php/linguadidaktika/article/view/7360

Kridalaksana, H. (2011). Kamus Linguistik. Jakarta: Gramedia.

Quirk, \& Randolp, e. a. (1987). A Comprehensive Grammar of The English Language. London: Longman. 